\title{
Effect of Protein Supplement Intake on Oral Health status of Bodybuilders. A Cross-sectional Study
}

\author{
AQ1 Rabaa Mahmoud ${ }^{1}$ D, Diana Mostafa ${ }^{2}$, Fatimah Saad Aldawsari ${ }^{3}$, Rawan Abdullah Almutairi ${ }^{3}$
}

${ }^{1}$ Department of Pediatric Dentistry and Dental Public Health, Mansoura University, Dakahlia, Mansoura City, Egypt; ${ }^{2}$ Department of Periodontology and Oral Medicine, Alexandria University, Alexandria, Egypt; ${ }^{3}$ General Dental Practitioner, Riyadh, Saudi Arabia

\begin{tabular}{|c|c|}
\hline & Abstract \\
\hline $\begin{array}{l}\text { Edited by: Slavica Hristomanova-Mitkovska } \\
\text { Citation: Mahmoud R, Mostafa D, Aldawsari FS, Almutairi } \\
\text { RA. Effect of Protein Supplement Intake on Oral Health }\end{array}$ & $\begin{array}{l}\text { AIM: This study was conducted to estimate the effect of protein, creatine, and amino acids supplements on the ora } \\
\text { health of bodybuilders. Furthermore, the oral health status of bodybuilders and non-bodybuilders was compared. }\end{array}$ \\
\hline $\begin{array}{r}\text { status of Bodybuilders. A Cross-sectional Study. Open } \\
\text { Access Maced J Med Sci. 2022 Jan 03; 10(D):41-46. https:// } \\
\text { doi.org/10.3889/oamjms.2022.7959 } \\
\text { Keywords: Whey protein; Supplement; Creatine; } \\
\text { Bodybuilders; Oral health } \\
\text { *Correspondence: Rabaa Mahmoud, Department }\end{array}$ & $\begin{array}{l}\text { METHODS: This cross-sectional study was conducted in Riyadh city between April and July 2021. About } 200 \\
\text { non-smokers Saudi men were recruited in the study which was allocated into two groups (100 subjects each) } \\
\text { bodybuilders and non-bodybuilders. Oral health indicators such as dental caries, plaque, and gingival indices were } \\
\text { measured. }\end{array}$ \\
\hline $\begin{array}{r}\text { of Pediatric Dentistry and Dental Public Health, } \\
\text { Mansoura University, Dakahlia, Mansoura City, Egypt. } \\
\text { E-mail: rabaa4444mahmoud @gmail.com } \\
\text { Received: } 15-\text { Nov-2021 } \\
\text { Revised: } 30-\text { Nov-2021 } \\
\text { Accepted: } 03-\text { Dec-2021 } \\
\text { Copyright: @ } 2022 \text { Rabaa Mahmoud, Diana Mostafa, } \\
\text { Fatimah Saad Aldawsari, Rawan Abdullah Almutairi } \\
\text { Funding: This research did not receive any financial } \\
\text { support } \\
\text { Competing Interests: The authors have declared that no } \\
\text { competing interests exist }\end{array}$ & $\begin{array}{l}\text { RESULTS: The decayed (D) and decayed, missed, and filled teeth (DMFT) mean scores were higher in the } \\
\text { bodybuilder group than in the non-bodybuilder ( } 4.47 \mathrm{vs.} 0.89 \text { for } \mathrm{D} \text {, and } 8.75 \mathrm{vs} \text {. } 4.58 \text { for DMFT). Furthermore, plaque } \\
\text { index (PI.I.) and gingival index (G.I.) showed the same result. About } 60 \% \text { of participants were taking protein only, } \\
\text { while } 37 \% \text { of them were taking a combination of protein, creatine, and amino acids. Only } 3 \% \text { were taking creatine } \\
\text { A positive significant association was found between the frequency of protein intake and mean D teeth score, PI.I. } \\
\text { and G.I. scores. A negative significant association was found between PI.I score and each of protein and combined } \\
\text { intake of protein, creatine, and amino acids. Regarding G.I., combined supplement intake, protein intake, duration, } \\
\text { and frequency of brushing were negatively associated with it }(\mathrm{p}=0.033,0.026,0.081 \text {, and } 0.010 \text {, respectively). }\end{array}$ \\
\hline $\begin{array}{l}\text { under the terms of the Creative Commons Attribution- } \\
\text { NonCommercial } 4.0 \text { International License (CC BY-NC 4.0) }\end{array}$ & $\begin{array}{l}\text { CONCLUSION: The mean D and DMFT scores were significantly higher in bodybuilders than non-bodybuilders } \\
\text { About } 100 \% \text { of the study participants were taken whey protein with frequency ranging from } 2 \text { to } 6 \text { times per day } \\
\text { In addition to that, the frequency of protein intake could be directly associated with increased dental caries, plaque } \\
\text { accumulation, and gingivitis. While the type of supplement intake whether protein and combined supplements were } \\
\text { associated with decreased plaque and gingival scores. Poor oral hygiene practices among bodybuilders may be the } \\
\text { real cause of their bad oral health. }\end{array}$ \\
\hline
\end{tabular}

\section{Introduction}

Bodybuilding is an activity that involves weightlifting, calorie intake, and rest. It provides an aesthetic, healthy, and balanced form of the body. It is no longer just a sport; it became a part of a culture called the "bodybuilding subculture" which is a group of people interested in building their muscles [1].

Bodybuilders undertake a high level of training and nutrition programs to build their muscles. To accelerate muscle gain, dietary supplements became popular among them. However, these supplements have some side effects such as cardiovascular, hepatic, and psychiatric disease [2]. Furthermore, the regular users of supplements have active caries and ignore the effect of these supplements on their dental health [3].

To have the desired body shape, there are several commercial supplements used by bodybuilders such as meal support, meal replacement, nitric oxide, post-workout, pre-workout shakes, protein powder, and bars. The type and pattern of consumption play a substantial role in oral health status, including dental caries, periodontal disease, and dental erosion [4].

Protein, amino acid, and creatine supplements are widely used to enhance muscle growth and performance of athletes and habitually active consumers [5]. The recommended daily dose of protein intake for normal persons is $0.83 \mathrm{~g}$ protein $/ \mathrm{kg}$ body weight per day [6], which represents around 10-12\% of total energy intake [7]. However, this dose may vary worldwide from one country to another [8].

The daily protein consumption for bodybuilders should be $2-4 \mathrm{~g} / \mathrm{kg}$ of body weight [9]. This large amount of protein can be consumed from a variety of dietary sources such as animal and plant proteins as well as supplements [10]. Nutritional supplements containing carbohydrates, protein, vitamins, and minerals are used in a variety of sporting fields to support athletes' recommended daily intake of nutrients, as well as to enhance their performance [11]. 
Supplements can be taken before, during, or after exercise/resistance training. Protein supplements before and after training increase muscle protein synthesis [12], [13]. Supplements aid in glycogen depletion, so most bodybuilders take carbohydrate supplements to increase glycogen stores which can aid in recovery [11], [14].

Glucose, fructose, dextrose, and maltodextrin are sugars found in bodybuilding supplements that can increase the risk of dental caries [15], [16]. The increased consumption of protein and carbohydrates supplements has a significant effect in increasing dental caries. Furthermore, dehydration during sporting activities could decrease the salivary washing effect and increase the impact of carbohydrates on dental caries [17], [18].

Creatine considered the legally most widely used substance for the past two decades. Its intake increases the resynthesize of phosphocreatine in the muscles, especially following high-intensity effort, resulting in improved work capacity and muscle mass [17], [19], [20].

Bodybuilders and athletes are considered new risk groups [21] and the most dental practitioners do not know about them, so every effort should be made to disseminate the culture of the effect of supplement intake on the oral health of bodybuilders. Furthermore, bodybuilders should know the effect of abnormal behavior and lifestyle on their oral health.

Few studies have evaluated the relationship between supplement intake and oral health in bodybuilders. Thus, this study aimed to examine the effect of protein, amino acids, and creatine supplements on dental caries and gingival health in bodybuilders.

\section{Methods}

This cross-sectional study was conducted in Riyadh city, Saudi Arabia, between April and July 2021. Clinical examination and data collection were done at Vision's dental clinics. At the beginning of the study, a summary of the purpose of the study was given to all participants and their informed consents were obtained.

\section{Sample size and sampling technique}

Our sample was based on a non-probability convenient sampling technique. As a result of COVID-19 lockdown, it was difficult to reach out to the target group and perform ideal randomization technique, so our sample size relied on the sample size of the previous studies conducted in the country (110 participants in Jeddah) [22] then we increased the participants' number to be 200 .

\section{Participants allocation}

The study subjects were allocated into two groups; Group I bodybuilders (100 subjects who took muscle supplements such as protein, amino acids, or creatine), Group II non-bodybuilders (100 healthy young non-exercising participants who did not perform any heavy practice or took any sports supplements).

\section{Inclusion criteria}

Saudi non-smokers males, with an age range from 20 to 29 years, were included in the study. They should be free from any systemic diseases and had at least 20 intact teeth.

\section{Exclusion criteria}

Females, old agers, orthodontic patients, or patients using any systemic medications or steroids in the past 6 months were excluded from the study.

\section{Data collection}

Data collection was done by two well-trained and calibrated dental interns under the supervision of one of the teaching staff at Vision's dental colleges. Information about age, duration, and frequency of brushing, types, and frequency of taking supplements was obtained from participants before the clinical examination.

Participants from both groups underwent clinical evaluation for their oral health status as follow; oral hygiene was evaluated through recording of Silness and LÖe plaque index (PI.I.) [23] for six selected teeth $[16,12,24,36,32$, and 44$]$, as each of the four surfaces of the selected teeth (buccal, lingual, mesial, and distal) was given a score from 0 to 3 , then the score of the four surfaces was added together and divided by four giving the accurate PI.I. of each tooth, and the scores of the six examined teeth were added together and divided by six to get the score for each individual. The gingival condition was evaluated using LÖe and Silness gingival index (G.I.) [24], which was scored and calculated using the same teeth and steps as in PI.I. Dental caries status was recorded using the DMFT index in which decayed $(D)$, missed $(M)$, and filled $(F)$ teeth were recorded according to the World Health Organization (WHO) criteria [25]. For both PI.I. and G.I., if any of the six selected teeth was missed, it will be replaced with the opposing tooth, and if it was also missing one of the adjacent teeth was examined [26].

\section{Statistical analysis}

Data were collected, tabulated, and analyzed using (International Business Machines Corporation, Statistical Package for the Social Sciences version 20, 
Table 1: Comparison of oral health indicators among bodybuilder and non-bodybuilder groups $(\mathrm{n}=100)$

\begin{tabular}{llllll}
\hline Variable & $\mathrm{D}$ & $\mathrm{M}$ & $\mathrm{F}$ & DMFT & Pl.I \\
\cline { 2 - 5 } & Mean \pm SD & & & & \\
\hline Bodybuilders & $4.47 \pm 2.007$ & $1.52 \pm 1.0960$ & $2.43 \pm 1.458$ & $2.75 \pm 1.794$ & $2.131 \pm 0.559$ \\
Non-bodybuilders & $0.89 \pm 1.278$ & $0.75 \pm 1.321$ & $2.94 \pm 1.033$ & $4.58 \pm 2.861$ & $0.68 \pm 0.30$ \\
p-value & 0.000 & 0.593 & 0.494 & 0.000 & 0.033 \\
\hline
\end{tabular}

*Significant differences by independent sample t-test at $p<0.05$

IL, USA). $p<0.05$ was set as the level of significance. Descriptive analysis was conducted using frequency with percentage for categorical variables and mean with standard deviation for numerical variables. Differences between the two means were done using an independent t-test. Linear regression analysis was used to analyze the association between dependent variables and other predictors in a multivariate environment and presented by $\mathrm{B}$, beta coefficient, and $95 \%$ confidence interval $(95 \% \mathrm{Cl})$.

\section{Results}

About 200 Saudi men with a mean age of 25.63 years participated in the study. Table 1 demonstrated the comparison of $\mathrm{D}, \mathrm{M}, \mathrm{F}, \mathrm{DMFT}$, PI.I, and G.I mean scores between bodybuilders and non-bodybuilders participants. Significant differences were found between D, DMFT, PL.I., and G.I. ( $p=0.000$, $0.000,0.033$, and 0.016 , respectively), where $D$ and DMFT were higher in the bodybuilder group than in non-bodybuilder (4.47 vs. 0.89 for D and 8.75 vs. 4.58 for DMFT). Furthermore, P.I. and G.I. showed the same result.

However, for the distribution of duration and frequency of brushing, there was a statistical difference between both groups regarding duration of brushing $(p=0.000)$ (Table 2). For the distribution of different types of supplements among our study participants, $60 \%$ of our participants were taking protein only, while $37 \%$ of them were taking a combination of protein, creatine, and amino acids. Only $3 \%$ were taking creatine (Figure 1).

The association between different predictors and oral health indicators was studied into linear regression analysis models, as with each unit increase in the frequency of protein intake, there was a significant increase in dental caries by 0.298 , G.I. by 0.358 , and PI.I. by 0.347 . A negative significant association was found between PI.I score and each of protein and combined intake of protein, creatine, and amino acids. Meaning that higher data entry codes reduced PI.I. score. Protein intake (0: no protein intake and 1: protein intake) induced reduction in PI.I. score by 0.536, the same also for combined supplement intake as it reduced PI.I. score by 0.675 (0: no combination intake and 1: combination intake). Regarding G.I., combined supplement intake, protein intake, duration, and frequency of brushing negatively associated with it ( $p=0.033,0.026,0.081$, and 0.010, respectively). For protein and combined supplements, the same data entry codes as PI.I. However, for frequency of brushing (1: once, 2: twice, and 3: 3 times), and duration of brushing (10: $10 \mathrm{~s}, 20: 20 \mathrm{~s}, 30: 30 \mathrm{~s}$, 3: $3 \mathrm{~min}, 60: 1 \mathrm{~min}$, and 120: $2 \mathrm{~min}$ ). This meant that toothbrushing for 2 min twice per day reduced G.I. by 0.230 and 0.155 folds for duration and frequency, respectively (Table 3 ).

\section{Discussion}

Bodybuilders are a growing target group, and the availability of over the counter (OTC) supplements in addition to the absence of control over advertisements promoting these products led to an increase in the demand from young people and adolescents to use them. Hence, it was necessary to explore this problem by performing extensive researches to prove or disproof the relation between supplement intake and oral health status among this group.

Our sample was taken from non-smoker males with ages ranging from 20 to 29 years as this is the popular age of most bodybuilders. Furthermore, the long-term effect of oral hygiene negligence and protein supplements intake can be studied among this age group.

About $100 \%$ of our participants were taking whey protein either alone or in combination with

Table 2: Distribution of Frequency and Duration of Toothbrushing in Both Bodybuilder and Non-Bodybuilder Groups Total ( $n=100)(\%)$

\begin{tabular}{llll}
\hline & Groups & Body builders & Non-Bodybuilders \\
\hline Duration of brushing (time in seconds) & 10 & 7 & 0 \\
& 20 & 4 & 0 \\
& 30 & 55 & 0 \\
& 60 & 27 & 10 \\
Frequency of brushing & 120 & 7 & 89 \\
& 180 & 0 & 1 \\
& Once & 46 & 0 \\
& Twice & 54 & 95 \\
\hline
\end{tabular}


Table 3: Linear regression analysis for the association between oral health indicators and different predictors in bodybuilders' participants $(n=100)$

\begin{tabular}{|c|c|c|c|c|c|c|c|}
\hline \multirow[t]{2}{*}{ Dependent variables } & \multirow[t]{2}{*}{ Predictors } & \multirow[t]{2}{*}{ Unstandardized coefficient (B) } & \multirow[t]{2}{*}{ Standardized coefficient (Beta) } & \multirow[t]{2}{*}{$\mathrm{T}$} & \multirow[t]{2}{*}{$p$-value } & \multicolumn{2}{|c|}{$95 \%$ confidence interval for B } \\
\hline & & & & & & Lower bound & Upper bound \\
\hline Decayed teeth & Frequency of protein intake & 0.846 & 0.298 & 2.866 & 0.005 & 0.260 & 1.432 \\
\hline \multirow{3}{*}{ Plaque index } & Combination & -0.765 & -0.675 & -2.533 & 0.013 & -1.365 & -0.165 \\
\hline & Protein & -0.605 & -0.536 & -2.022 & 0.046 & -1.199 & -0.011 \\
\hline & Frequency of protein intake & 0.272 & 0.347 & 3.673 & 0.000 & 0.125 & 0.419 \\
\hline \multirow[t]{5}{*}{ Gingival index } & Combination & $-.556-$ & -0.564 & -2.168 & 0.033 & -1.065 & -0.047 \\
\hline & Protein & -0.575 & -0.587 & -2.266 & 0.026 & -1.079 & -0.071 \\
\hline & Frequency of protein intake & 0.244 & 0.358 & 3.876 & 0.000 & 0.119 & 0.368 \\
\hline & Frequency of brushing & -0.148 & -0.155 & -1.761 & 0.081 & -0.316 & 0.019 \\
\hline & Duration of brushing & -0.008 & -0.230 & -2.646 & 0.010 & -0.014 & -0.002 \\
\hline
\end{tabular}

other supplements with frequency 2-6 times per day. While $37 \%$ of them were taking creatine and amino acids with frequency 1-2 times per day in addition to protein with its regular frequency. Only $3 \%$ were taking creatine and no one was taking amino acids alone as it was taken in combination with creatine and whey protein. Whey protein was known for its antimicrobial activity and immune modulation; it also improves muscle strength and body composition. In addition to that, it prevents cardiovascular disease and osteoporosis. There are several different whey protein products; whey protein concentrates (ranging from 80 to $95 \%$ protein), reduced lactose whey, whey protein isolate, demineralized whey, and hydrolyzed whey. Whey products differ in the amount of protein, carbohydrates, immunoglobulins, lactose, minerals, and fat. These variables are determinant factors for the selection of a certain type of whey according to the nutritional purpose [27]. Al Saffan et al. [28] conducted a study to evaluate the effect of sport on oral health in Riyadh city, Saudi Arabia. Their findings showed that $61.2 \%$ of their sample were taking protein, while $83.6 \%$ of them were taking a combination of amino acids, protein, and creatine.

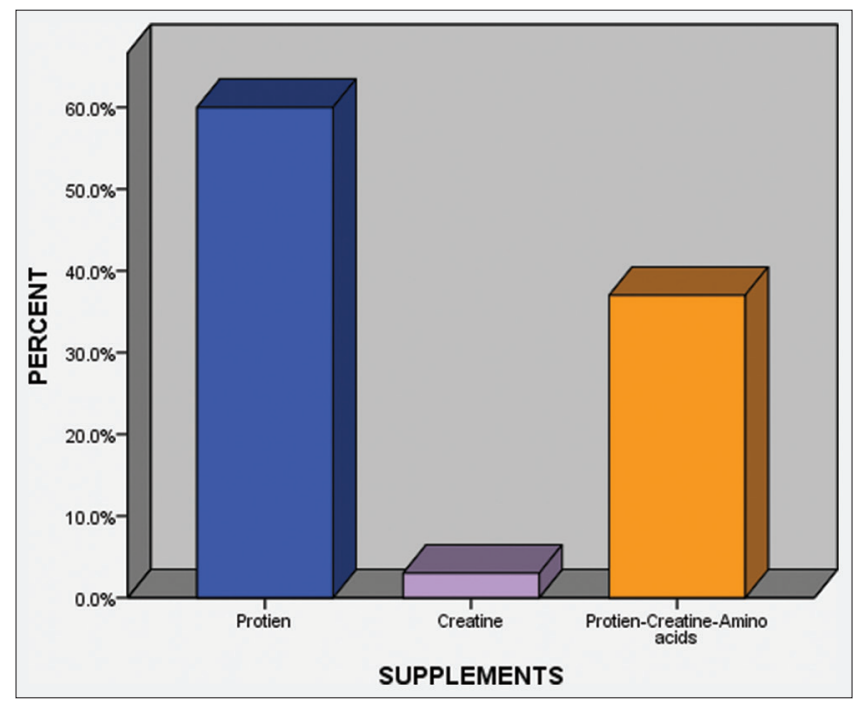

Figure 1: Relative frequency of different supplement intake among bodybuilders $(n=100)$

Our results revealed that $D$ teeth and decayed, missed, and filled teeth (DMFT) were significantly higher in bodybuilders than non-bodybuilders. Furthermore, the regression analysis results supported the same finding as a positive significant association was found between frequent protein intake and dental caries. This means that by increasing the frequency of protein intake there is an increase in its amount which is directly related to an increase in glucose and sucrose levels. It was found that daily intake of protein supplement with frequency $7-8$ times is equivalent to $107.9 \mathrm{~g}$ of sugar which can be increased by increasing the dosages of the supplements. This could explain the higher caries rate among bodybuilders and explain the positive significant relation between dental caries and increased frequency of protein intake [22]. This could be further demonstrated by the relation between the frequent sugar intake and the reduced salivary $\mathrm{pH}$ beyond 5.5, without enough time for salivary recovery and continued demineralization episodes leading to dental caries [29], [30].

The study findings revealed that the mean PI.I. score was significantly higher in bodybuilders than their counterparts. This could be explained by the poor oral hygiene practice in bodybuilders in comparison to non-bodybuilders, as $55 \%$ of bodybuilders brush their teeth for $30 \mathrm{~s}$ only which is insufficient time for brushing in comparison to $89 \%$ of non-bodybuilders who were brushing their teeth for $120 \mathrm{~s}$ (2-min) which is the recommended duration for toothbrushing. Furthermore, only $54 \%$ of bodybuilders versus $95 \%$ of non-bodybuilders were brushing their teeth twice daily. The same findings could further explain the higher G.I. mean score in bodybuilders than nonbodybuilder, as there is a positive relationship between poor oral hygiene practice, plaque accumulation, and gingival inflammation [31]. Several studies revealed that oral health among athletes is poor; in London, a study was conducted at (2013) to evaluate the effects of supplement intake on oral health among a sample of (2012) London Olympic Games Athletes. The study results cleared that $76 \%$ of the participants had gingivitis, while $55 \%$ showed signs of dental caries [20]. Furthermore, the result of 16 studies included in a systematic review conducted in 2015 supported the same finding, as the prevalence of dental caries ranged from $15 \%$ to $75 \%$, while the irreversible moderate-tosevere periodontal diseases reached up to $15 \%$ and gingivitis up to $76 \%$ among athletes [32]. In addition to them, Knight et al. [33] performed a study in Riyadh city and found a relation between the increased consumption of supplements intake and poor oral health. In the same vein, Al Saffan et al. [28] cleared that $81.7 \%$ and $76.6 \%$ 
of their participants who took supplements and protein, respectively, demonstrated poor oral hygiene which could be attributed to the insufficient methods of oral hygiene among their participants as they explained. In addition to that, $6.9 \%$ only of the participants were brushing their teeth twice/day versus to $56.9 \%$ who were brushing once/day.

The study results showed that the combined supplement (protein, creatine, and amino acids) and protein intake had negative significant relation with plaque accumulation and gingival inflammation. That means by increasing these supplement intakes there was an improvement of oral and gingival health. These data did not support the previous findings that PL.I and G.I scores were higher in bodybuilders than non-bodybuilders. This conflict could be explained by the poor oral hygiene practice among bodybuilders as demonstrated before. The mechanism of action of supplements on periodontal health was demonstrated by Aral et al. [34] who cleared that interleukins

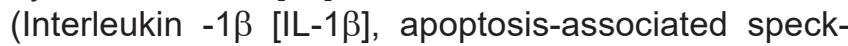
like protein containing C-terminal caspase-recruitment domain (ASC), and caspase 1 [CASP1]) may play a key roles in the pathogenesis of gingivitis. Furthermore, they demonstrated that bodybuilding and protein powder supplement intake may decrease gingival inflammation by downregulating CASP1, IL-1 $\beta$, and ASC. In the same line of that finding, Pullishery et al. [21] found that community periodontal index scores in bodybuilders $(11.34 \pm 4.6)$ were lower than non-bodybuilders (13.98 \pm 5.54$)$. Furthermore, the periodontal pockets of $4-5 \mathrm{~mm}$ were more prevalent in non-bodybuilders than bodybuilders ( $80.7 \%$ vs. $49.1 \%$, respectively). A positive correlation was found between the periodontal pocket of $4-5 \mathrm{~mm}$ and average protein supplements intake, frequency, and duration of its intake. They concluded that periodontal health was significantly better among bodybuilders and there could be a relationship between periodontal health and protein intake.

\section{Conclusion}

From the previous findings, mean $\mathrm{D}$ and DMFT scores were significantly higher in bodybuilders than non-bodybuilders. About $100 \%$ of the study participants were taken whey protein with frequency ranging from 2 to 6 times per day. In addition to that, the frequency of protein intake could be directly associated with increased dental caries, plaque accumulation, and gingivitis. While the type of supplement intake whether protein and combined supplements were associated with decreased plaque and gingival scores. Poor oral hygiene practices among bodybuilders may be the real cause of their bad oral health.

\section{Ethics Approval and Consent to Participate}

The study was approved by the Ethical Committee at Vision private colleges in Riyadh city, KSA. Informed consent was taken from the participants at the beginning of the study.

\section{Availability of Data and Materials}

The datasets used and/or analyzed during the present study are available from the corresponding author on reasonable request.

\section{Authors' Contributions}

$\mathrm{RM}^{1}$ wrote the whole manuscript, analyzed and interpreted the results, reviewed, and approved the final manuscript. $\mathrm{DM}^{2}, \mathrm{FSA}^{3}$, and $\mathrm{RAA}^{4}$ participated in data collection and final revision of the manuscript.

\section{Acknowledgment}

The author would like to express her deep gratitude and thanks to all the participants and staff of Gold Gym, Body Masters, and Fitness Time, Riyadh, Saudi Arabia, for their help and support of our research. Also, I would like to thank the internship students who participated in collecting data for this research. 
Community Dent Oral Epidemiol. 2018;46:563-8.

5. Bianco A, Mammina C, Paoli A, Bellafiore M, Battaglia G Caramazza G, et al. Protein supplementation in strength and conditioning adepts: Knowledge, dietary behavior and practice in Palermo, Italy. J Int Soc Sports Nutr. 2011;8(1):25. https://doi. org/10.1186/1550-2783-8-25

\section{PMid:22206347}

6. EFSA Panel on Dietetic Products, Nutrition, and Allergies. Scientific opinion on dietary reference values for protein. EFSA J. 2012;10:2557.

7. European Food Safety Authority. Scientific and technical assistance on food intended for sportspeople. EFSA Suppl Pub. 2015;12:871E.

8. Sánchez-Muniz F, Codina SL. En: Libro Blanco De La Nutrición En España. Madrid, Spain: Fundación Española de la Nutrición; 2013. p. 113-24.

9. Burke DG, Chilibeck PD, Davidson KS, Candow DG, Farthing J, Smith-Palmer T. The effect of whey protein supplementation with and without creatine monohydrate combined with resistance training on lean tissue mass and muscle strength. Int J Sport Nutr Exerc Metab. 2001;11(3):349-64. https://doi.org/10.1123/ ijsnem.11.3.349

PMid:11591884

10. Hoffman JR, Falvo MJ. Protein which is best? J Sports Sci Med. 2004;3(3):118-30.

PMid:24482589

11. Aoi W, Naito $Y$, Yoshikawa T. Exercise and functional foods. Nutr J. 2006;5:15. https://doi.org/10.1186/1475-2891-5-15 PMid: 16749944

12. Tipton KD, Rasmussen BB, Miller SL, Wolf SE, Owens-Stovall SK, Petrini BE, et al. Timing of amino acid-carbohydrate ingestion alters anabolic response of muscle to resistance exercise. Am J Physiol Endocrinol Metab. 2001;281:E197-206. https://doi. org/10.1152/ajpendo.2001.281.2.E197

PMid: 11440894

13. Tipton KD, Elliott TA, Cree MG, Wolf SE, Sanford AP, Wolfe RR. Ingestion of casein and whey proteins result in muscle anabolism after resistance exercise. Med Sci Sports Exerc. 2004;36(12):2073-81. https://doi.org/10.1249/01. mss.0000147582.99810.c5

PMid:15570142

14. Haff GG, Lehmkuhl MJ, McCoy LB, Stone MH. Carbohydrate supplementation and resistance training. J Strength Cond Res. 2003;17:187-96. https://doi. org/10.1519/1533-4287(2003)017<0187:csart>2.0.co;2 PMid:12580676

15. Granny TH, Mistry M. Properties of maltodextrins and glucose syrups in experiments in vitro and the diets of laboratory animals, relating to dental health. Br J Nutr. 2000;84(4):565-74. PMid: 11103228

16. Moynihan PJ, Mcllmoyle S, Rowshanaei R, Moxon R, Russell RRB. Acidogenic potential of fructo-oligosaccharides: Incubation studies and plaque pH studies. Caries Res. 2001;35:275.

17. Harris RG, Viru M, Greenhaff PL, Hultman E. The effect of oral creatine supplementation on running performance during maximal short-term exercise in man. J Physiol. 1993;467:74.

18. Ingwall JS. Creatine and the control of muscle-specific protein synthesis in cardiac and skeletal muscle. Circ Res. 1976;38:115-23.

PMid:1269086

19. Kruszewski M, Wit B, Buśko K, Kępa G. Effect of Powerlifting Training Supplemented by Creatine on Sports Results and Body Components. Ipoh, Malaysia: Lee CP, editor. Proceeding $2^{\text {nd }}$ International Conference Weightlifting and Strength Training;
2000. p. 103

20. Needleman I, Ashley P, Fine P, Haddad F, Loosemore M, de Medici A. Consensus statement: Oral health and elite sports performance. Br Dent J. 2014;217(10):587-90. https://doi. org/10.1038/sj.bdj.2014.1000

PMid:25415018

21. Pullishery F, Dada AM, Aboelaza MR, Shalaby MA. Periodontal status of 33-44-year-old male bodybuilders and its relationship with protein supplement intake: An observational comparative study. Adv Hum Biol. 2020;10:176-81.

22. Moynihan PJ, Kelly SA. Effect on Caries of restricting sugar intake: Systematic review to inform WHO guidelines. J Dent Res. 2013;93(1):8-18. https://doi.org/10.1177/0022034513508954 PMid:24323509

23. Silness $J$, Löe $H$. Periodontal disease in pregnancy. II. Correlation between oral hygiene and periodontal condition. Acta Odontol Scand. 1964;22:121-35. https://doi. org/10.3109/00016356408993968

PMid: 14158464

24. Löe H, Silness J. Periodontal disease in pregnancy. I. Prevalence and severity. Acta Odontol Scand. 1963;21:533-51. https://doi. org/10.3109/00016356309011240 PMid: 14121956

25. World Health Organization. Oral Health Surveys. Basic Methods $5^{\text {th }}$ ed. Geneva, Switzerland: World Health Organization; 2013.

26. Özçaka Ö, Becerik S, Bıçakcı N, Kiyak AH. Periodontal disease and systemic diseases in an older population. Arch Gerontol Geriatr. 2014;59(2):474-9. https://doi.org/10.1016/j. archger.2014.05.011

PMid:25015876

27. Marshall K. Therapeutic applications of whey protein. Altern Med Rev. 2004;9(2):136-56

PMid:15253675

28. Al Saffan A, Alshahry RM, Alrwissan SA, Aljanoubi ZA, Alswailem RA. The effect of sports on oral health in Riyadh city: A cross-sectional study. Saudi J Oral Sci. 2020;7:18-23.

29. Touger-Decker R, van Loveren C. Sugar and dental caries. Am J Clin Nutr. 2003;78:881S-2. https://doi.org/10.1093/ ajcn/78.4.881S PMid: 14522753

30. Myonihan PJ, Kelly SAM. Effect on caries of restricting sugars intake: Systematic review to inform WHO guidelines. J Dent Res. 2013;93(1):8-18. https://doi.org/10.1177/0022034513508954 PMid:24323509

31. Rahman B, Kawas SA. The relationship between dental health behavior, oral hygiene and gingival status of dental students in the United Arab Emirates. Eur J Dent. 2013;7(1):22-7. PMid:23408498

32. Ashley P, Di lorio A, Cole E, Tanday A, Needleman I. Oral health of elite athletes and association with performance: A systematic review. Br J Sports Med. 2015;49:14-9. https://doi.org/10.1136/ bjsports-2014-093617 PMid:25388551

33. Knight A, Alsaey M, Farooq A, Wilson MG. Alarmingly poor oral health in international athletes competing in the Middle East. Br J Sports Med. 2019;53(16):1038-9. https://doi.org/10.1136/ bjsports-2017-098770 PMid:29691290

34. Aral K, Berdeli E, Aral CA, Berdeli A, Atan M. Effects of bodybuilding and protein supplements in saliva, gingival crevicular fluid, and serum. J Oral Sci. 2017;59(1):121-30. https://doi.org/10.2334/josnusd.16-0367

PMid:28367892 